\title{
Effects of the Plains Pocket Gopher (Geomys bursarius) on Rangeland
}

\author{
M.A. FOSTER AND J. STUBBENDIECK
}

\begin{abstract}
Gophers reduced forage production by 18 to $49 \%$ on sands and silty range sites in western Nebraska. Determination of percentages of the soil surface that were bare, covered by litter, and occupied by plant bases showed that gopher-disturbed areas contained greater percentages of bare soil and litter than did undisturbed areas. Basal cover of vegetation was highest on undisturbed areas. Frequency of vegetation on gopher mounds of different age was determined. Most perennial grasses increased in frequency on mounds with increasing mound age, while annual grasses and forbs decreased.
\end{abstract}

Pocket gophers are common throughout the Great Plains and are found in a wide variety of soil and vegetation types. The Plains pocket gopher (Geomys bursarius) is abundant in western Nebraska. These rodents affect rangeland by harvesting vegetation, burying litter and vegetation, and reducing plant vigor (Case et al. 1976). The plains pocket gopher is usually restricted to sandy and silty soils from the Rocky Mountains east to the Mississippi River, and from Canada to southern Texas. Downhower and Hall (1966) concluded that plains pocket gophers in Kansas occurred only in soils with a low clay content (less than $30 \%$ ) and high sand content (more than $40 \%$ ), and they were not affected by presence or absence of silt. In Colorado, these rodents are common in alfalfa fields, sandhill rangelands, and river bottoms, but are not abundant in shortgrass prairies or areas with compacted soils (Turner et al. 1973).

Grasses constitute the bulk of the diet of the plains pocket gopher, but forbs which are more succulent are also utilized when available. Myers and Vaughan (1964) examined stomach contents of plains pocket gophers taken in the sandhills of eastern Colorado, and determined that approximately $64 \%$ of the yearly diet was grass. Plants most commonly caten were needleandthread (Stipa comata), western wheatgrass (Agropyron smithii), blue grama (Bouteloua gracilis), and pricklypear cactus (Opuntia humifusa). The authors also determined that the diet contained $31 \%$ stems and leaves and 69\% roots. During spring and summer when forbs were most abundant, grasses comprised approximately $58 \%$ of the diet. However, during fall and winter when forbs were not growing, the diet consisted of $74 \%$ grasses. Beck and Hansen (1966) found plains pocket gophers in eastern Colorado to be more abundant on sandy loam soils compared to a dune sand type. There was a greater relative abundance of plants commonly utilized for food on the sandy loam soil, which could have accounted for the increased number of gophers.

Authors are graduate research assistant, University of Nebraska Panhandle Station, Scottsbluff, Nebraska 69361, and associate professor of agronomy (range management), University of Nebraska, Lincoln, 68583. Mr. Foster is currently research associate, Texas A\&M University Agricultural Research and Extension Center, Vernon. Texas 76384.

This report is a contribution of the Nebraska Agricultural Experiment Station as Technical Paper Number 5586.
The literature contains little information concerning the effects of the plains pocket gopher on forage production and soil cover, although, numerous studies have centered on the northern pocket gopher (Thomomys talpoides). Turner (1969) reported that on Grand Mesa, Colorado, herbage available to livestock was increased by $218 \mathrm{~kg} / \mathrm{ha}$ after 1 year of gopher control, and the crown cover of plants commonly eaten by gophers increased. The initial increase in available herbage resulted primarily from reduced burial and consumption of herbage by gophers. Fitch and Bently (1949) studied the pocket gopher, ground squirrel, and kangaroo rat in California. The gopher was thought to be the most destructive of the three to vegetation. The authors concluded that if the gophers (at a density of $25 / \mathrm{ha}$ ) destroyed vegetation on rangeland at the same rate as in the experiment, $284 \mathrm{~kg} / \mathrm{ha}$ would be destroyed during the greenforage season.

Gopher mounds may cover $25 \%$ of the soil surface; however, 5 to $15 \%$ is more common (Turner et al. 1973). Downhower and Hall (1966) reported that one gopher may transport 2 tons of soil to the surface per year. The deposited soil may prevent further growth of the underlying vegetation. Since the mounds are not protected by vegetation for some time, accelerated wind and water erosion may occur. Plant succession on pocket gopher mounds progresses as it would on any denuded area. Ellison (1946) concluded that gopher mounds in uneroded areas with good plant cover made poor seed beds; however, favorable seedbeds occurred where erosion had taken place and the plant cover was greatly reduced. Laycock (1953) studied the northern pocket gopher in the Jackson Hole region of Wyoming. Results showed that new plants appeared on very few mounds the season they were made, and there were two types of plants involved in revegetation: (1) plants growing through the mounds although covered by soil, and (2) plants starting from seed in the mounds. Few plant species were found growing on mounds in the sagebrush and aspen communities where soil was probably too dry for seed germination. The average number of plants growing on mounds in the streamside forest community was relatively high because the soil remained moist throughout the summer. Ellison (1946) and Moore and Reid (1951) concluded that at least some plants were killed when covered by gopher mounds, which contributes to the low frequency of vegetation found on newly created mounds. Laycock (1958) found a high percentage of annuals growing on mounds. The author concluded that where the pocket gopher was part of the biotic community, the mounds were microsites where pioneer species (annuals) were continually perpetuated. Thus, stable or climax communities as well as disturbed areas would always include pioneer species.

This study was conducted in 1975 and 1976 to evaluate the effects of the plains pocket gopher on forage production and 
species composition on two range sites in western Nebraska. In addition, plant succession on mounds was recorded.

\section{Study Area and Methods}

The study area was located in northwestern Nebraska on the Pepper Creek Ranch, approximately $56 \mathrm{~km}$ southeast of Chadron. Climate of the area is semiarid, and the 30-year (1941-1970) mean annual precipitation for Chadron was $399 \mathrm{~mm}$, with $69 \%$ occurring during the 130-day growing season (U.S. Dept. of Commerce 1973). Precipitation during the study was below average, with only $270 \mathrm{~mm}$ occurring in 1975 and $380 \mathrm{~mm}$ in 1976.

Investigations were conducted at four research locations on the Pepper Creek Ranch: North Sand Canyon (NSC), South Sand Canyon (SSC), Rough (R), and West Potash (WP). Two range sites occurred on the study arca: sands in NSC and SSC and silty in R and WP. Soil types were Valent and Dwyer loamy fine sand on the sand range sites, and Alliance silt loam on the silty range sites. Range condition was determined on gopher-disturbed and undisturbed areas on the study arca in 1975 and 1976 (Table 1). Plant species varied between research locations, and their presence or absence was of value to characterize the range sites (Table 2).

Table 1. Range condition (\% of climax) on plains pocket gopher disturbed and undisturbed areas in 1975 and 1976.

\begin{tabular}{lclcc}
\hline & & & \multicolumn{2}{c}{ Range condition \% } \\
\cline { 5 - 5 } Research location & Range site & Area & 1975 & 1976 \\
\hline NSC & Sands & Disturbed & 57 & 56 \\
& & Undisturbed & 69 & 71 \\
SSC & \multirow{3}{*}{ Sands } & Disturbed & 57 & 58 \\
& & Undisturbed & 82 & 84 \\
R & Silty & Disturbed & 29 & 27 \\
& & Undisturbed & 48 & 49 \\
WP & Silty & Disturbed & 27 & 26 \\
& & Undisturbed & 31 & 32 \\
\hline
\end{tabular}

\section{Forage Production}

Preliminary investigations in 1974 revealed that pocket gophers affected forage production on rangcland and suggested that further research was needed to assess the problem. Both gopher-disturbed and undisturbed areas, each measuring $64 \mathrm{~m} \times 64 \mathrm{~m}(0.4 \mathrm{ha})$, were delineated at each of the four research locations in March, 1975. Disturbed and undisturbed arcas at each research location were divided into four $16 \mathrm{~m}-64 \mathrm{~m}(0.1 \mathrm{ha})$ replications. A series of ten compass lines were established, using a random numbers table, across each replication of the gopher-disturbed and undisturbed areas of the range. In September of each year, vegetation in ten $0.1-\mathrm{m}^{2}$ quadrats located by the use of a random numbers table was clipped at $2 \mathrm{~cm}$ above the soil surface and dried to a constant weight.

\section{Soil, Litter, and Basal Cover}

A modified 10-point sampling frame was used to determine the percentage of bare soil, litter, and basal cover of vegetation. Sampling points were located along a series of ten compass lines established in the same manner as those used in the forage production determinations. The point frame was systematically placed at each location along the lines and a record was made of what each pin contacted at the soil surface (i.e., bare soil, litter, or basal cover of individual plant species). Two thousand points were read in each replication in August of each year.

\section{Frequency of Vegetation on Mounds}

One-hundred and fifty mounds were permanently marked in 1974 on the SSC and R research locations and were separated into age categories of less-than-1-year, 1-year, and 2-years. Fifty additional mounds were marked in April of 1975 and 1976, for a total of 250 mounds at each of the two locations. Therefore, when vegetation
Table 2. Plant species present on the Papper Creek Ranch study area.

\begin{tabular}{|c|c|c|c|c|}
\hline \multirow[b]{2}{*}{ Species } & \multicolumn{2}{|c|}{ Sands sites } & \multicolumn{2}{|c|}{ Silty sites } \\
\hline & NSC & SSC & $\mathbf{R}$ & WP \\
\hline \multicolumn{5}{|l|}{ Perennial grasses } \\
\hline Blue grama (Bouteloua gracilis) & $\mathrm{X}$ & $\mathrm{X}$ & $\mathrm{X}$ & $\mathrm{X}$ \\
\hline Buffalograss (Buchloe dactyloides) & & & & $\mathrm{X}$ \\
\hline Indian ricegrass (Oryzopsis & & & & \\
\hline hymenoides) & $\mathrm{X}$ & $\mathrm{X}$ & & \\
\hline Needleandthread (Stipa comata) & $\mathrm{X}$ & $\mathrm{X}$ & $\mathrm{X}$ & $\mathrm{X}$ \\
\hline $\begin{array}{l}\text { Prairie junegrass (Koeleria } \\
\text { pyramidata) }\end{array}$ & $\mathbf{X}$ & $\mathbf{X}$ & $\mathbf{x}$ & $\mathrm{Y}$ \\
\hline Prairie sandreed (Calamovilfa & $\boldsymbol{\lambda}$ & $\boldsymbol{\Lambda}$ & $\lambda$ & $\lambda$ \\
\hline longifolia) & $\mathrm{X}$ & $\mathrm{X}$ & $\mathrm{X}$ & $\mathrm{X}$ \\
\hline Red threeawn (Aristida longiseta) & $\mathrm{X}$ & $\mathrm{X}$ & $\mathrm{X}$ & $\mathrm{X}$ \\
\hline Sand bluestem (Andropogon hallii) & $X$ & $\mathrm{X}$ & & \\
\hline $\begin{array}{l}\text { Sand dropseed (Sporobolus } \\
\text { cryptandrus) }\end{array}$ & $\mathrm{X}$ & $\mathrm{x}$ & $\mathrm{X}$ & \\
\hline $\begin{array}{l}\text { Sandhill muhly (Muhlenbergia } \\
\text { pungens) }\end{array}$ & $\mathrm{X}$ & $\mathrm{X}$ & & \\
\hline Tall dropseed (Sporobolus asper) & $\mathrm{X}$ & $\mathrm{X}$ & $\mathrm{X}$ & \\
\hline Threadleaf sedge (Carex filifolia) ${ }^{1}$ & $\mathrm{X}$ & $\mathrm{X}$ & $\mathrm{X}$ & $\mathrm{X}$ \\
\hline $\begin{array}{l}\text { Western wheatgrass (Agropyron } \\
\text { smithii) }\end{array}$ & $\mathrm{X}$ & $\mathrm{X}$ & $\mathrm{X}$ & $\mathrm{X}$ \\
\hline Annual grasses & & & & \\
\hline Downy brome (Bromus tectorum) & $\mathrm{X}$ & $\mathrm{X}$ & $\mathrm{X}$ & $\mathrm{X}$ \\
\hline Sixweeks fescue (Vulpia octoflora) & $\mathrm{X}$ & $\mathrm{X}$ & $\mathrm{X}$ & $\mathrm{X}$ \\
\hline
\end{tabular}

\section{Perennial forbs}

Curlycup gumweed (Grindelia squarrosa)

Heath aster (Aster ericoides)

Lemon scurf pea (Psoralea

lanceolata)

Plains pricklypear (Opuntia poly cantha)

Purple prairie clover (Petalostemon purpureum)

Rush skeletonplant (Lygodesmia

juncea)

Shell-leaf penstemon (Penstemon grandiflorus)

Silvery lupine (Lupinus argenteus)

Slimflower scurf pea (Psoralea tenuiflora)

Texas croton (Croton texensis)

Western ragweed (Ambrosia

psilostachya)

Annual forbs

Annual criogonum (Eriogonum

annuum)

Buffalo bur (Solanum rostratum)

Lambsquarters (Chenopodium album)

Spotted beebalm (Monarda pectinata)

Fendler cryptantha (Cryptantha

fendleri)

Woolly plantain (Plantago patagonica

$\begin{array}{cccc}\mathrm{X} & \mathrm{X} & \mathrm{X} & \\ \mathrm{X} & \mathrm{X} & & \\ \mathrm{X} & \mathrm{X} & \mathrm{X} & \mathrm{X} \\ \mathrm{X} & \mathrm{X} & \mathrm{X} & \mathrm{X} \\ & \mathrm{X} & \mathrm{X} & \mathrm{X} \\ \mathrm{X} & \mathrm{X} & \mathrm{X} & \mathrm{X} \\ \mathrm{X} & \mathrm{X} & \mathrm{X} & \\ & & \mathrm{X} & \mathrm{X} \\ \mathrm{X} & \mathrm{X} & \mathrm{X} & \mathrm{X} \\ \mathrm{X} & \mathrm{X} & \mathrm{X} & \\ \mathrm{X} & \mathrm{X} & \mathrm{X} & \mathrm{X}\end{array}$

Shrubs

Cudweed sagewort (Artemisia

ludoviciana)

Fringed sagewort (Artemisia frigida)

$\begin{array}{cccc}\mathrm{X} & \mathrm{X} & \mathrm{X} & \mathrm{X} \\ \mathrm{X} & \mathrm{X} & & \\ \mathrm{X} & \mathrm{X} & & \\ \mathrm{X} & \mathrm{X} & \mathrm{X} & \mathrm{X} \\ \mathrm{X} & \mathrm{X} & \mathrm{X} & \mathrm{X} \\ \mathrm{X} & \mathrm{X} & \mathrm{X} & \mathrm{X}\end{array}$

'Grass-like plant

frequency was determined in August of 1976, mounds were less than$1-,-1-, 2-, 3-$, or 4-year old.

\section{Results}

\section{Forage Production}

The NSC research location (sands range site) was in good range condition on gopher-disturbed and high good on 
Table 3. Oven dry forage production ( $\mathrm{kg} / \mathrm{ha}$ ) from plains pocket gopherdisturbed and undisturbed areas.

\begin{tabular}{llrrr}
\hline \hline Research location & Area & \multicolumn{3}{c}{ Year } \\
\cline { 3 - 5 } & & 1975 & 1976 & Average \\
\hline NSC & Disturbed & 1054 & 1411 & $1233^{b 1}$ \\
& Undisturbed & 1669 & 2155 & $1912^{a}$ \\
SSC & Disturbed & 1105 & 1801 & $1453^{b}$ \\
& Undisturbed & 2107 & 3338 & $2723^{a}$ \\
R & Disturbed & 665 & 672 & $669^{b}$ \\
& Undisturbed & 1307 & 1316 & $1312^{a}$ \\
WP & Disturbed & 638 & 605 & $622^{b}$ \\
& Undisturbed & 778 & 806 & $792^{a}$ \\
\hline
\end{tabular}

Means within research locations with different superscripts are significantly different at the 0.05 level of probability.

undisturbed range (Table 1). The 2-year average forage production was $1,912 \mathrm{~kg} / \mathrm{ha}$ on undisturbed range and 1,233 $\mathrm{kg} / \mathrm{ha}$ on disturbed areas (Table 3). Range condition on SSC (sands range site) was good on disturbed and excellent on undisturbed range. The 2-year average forage production was $2,723 \mathrm{~kg} / \mathrm{ha}$ on undisturbed and $1,453 \mathrm{~kg} / \mathrm{ha}$ on disturbed areas (Table 3).

Gopher-disturbed areas at the $\mathrm{R}$ location (silty range site) were in low fair range condition, while undisturbed areas were in high fair condition (Table 1). Forage production averaged $1,312 \mathrm{~kg} / \mathrm{ha}$ on undisturbed and $669 \mathrm{~kg} / \mathrm{ha}$ on disturbed areas during the study (Table 3). The WP location (silty range site) was in low fair range condition on both disturbed and undisturbed areas (Table 1). During 1975 and 1976, forage production averaged $792 \mathrm{~kg} / \mathrm{ha}$ on undisturbed and $622 \mathrm{~kg} / \mathrm{ha}$ on gopher-disturbed areas (Table 3 ).

Soil, Litter, and Basal Cover

Bare soil was more abundant on gopher-disturbed areas as compared to undisturbed range during both years of the study (Table 4). The sands range sites (NSC and SSC) had higher percentages of bare soil than either silty range site ( $R$ and WP) on both disturbed and undisturbed areas.

Litter was generally more abundant on gopher-disturbed areas than on undisturbed range, with the highest percentages occurring on sands range sites (Table 4). Basal cover of vegetation was greatest on undisturbed areas at all research locations (Table 4).
Percentage basal vegetation cover was divided into the following classes: (1) perennial grasses, (2) annual grasses, (3) perennial forbs, (4) annual forbs, and (5) shrubs. Higher percentages of perennial grasses were present on undisturbed range as compared to disturbed areas (Table 5). Disturbed areas were significantly lower in basal cover of perennial grasses than undisturbed range at all research locations.

Table 5. Average percentage basal vegetation cover over a two year period on gopher disturbed and undisturbed areas.

\begin{tabular}{|c|c|c|c|c|c|}
\hline \multirow[t]{2}{*}{ Vegetation class } & \multirow[t]{2}{*}{ Area } & \multicolumn{2}{|c|}{ Sands sites } & \multicolumn{2}{|c|}{ Silty sites } \\
\hline & & NSC & SSC & $\mathbf{R}$ & WP \\
\hline & & \multicolumn{4}{|c|}{$\%$} \\
\hline \multirow{2}{*}{ Perennial grasses ${ }^{1}$} & ${ }^{1}$ Disturbed & $62.12^{b 1}$ & $52.49^{b}$ & $50.22^{b}$ & $64.22^{\circ}$ \\
\hline & Undisturbed & $89.79^{a}$ & $85.38^{a}$ & $66.84^{a}$ & $75.12^{\circ}$ \\
\hline \multirow[t]{2}{*}{ Annual grasses } & Disturbed & $8.19^{a}$ & $18.68^{a}$ & $26.70^{a}$ & $13.27^{\circ}$ \\
\hline & Undisturbed & $3.01^{b}$ & $5.84^{b}$ & $15.05^{b}$ & $11.95^{\circ}$ \\
\hline \multirow[t]{2}{*}{ Perennial forbs } & Disturbed & $16.41^{a}$ & $17.21^{a}$ & $4.60^{a}$ & $9.64^{a}$ \\
\hline & Undisturbed & $4.56^{b} \mathrm{a}$ & $7.79^{b}$ & $6.32^{a}$ & $3.17^{b}$ \\
\hline \multirow[t]{2}{*}{ Annual forbs } & Disturbed & $11.08^{a}$ & $6.72^{a}$ & $15.32^{a}$ & $11.38^{a}$ \\
\hline & Undisturbed & $2.24^{b}$ & $.89^{b}$ & $8.46^{b}$ & $8.23^{b}$ \\
\hline \multirow[t]{2}{*}{ Shrubs } & Disturbed & $2.20^{u}$ & $4.90^{a}$ & $3.16^{a}$ & $1.49^{a}$ \\
\hline & undisturbed & $.40^{b}$ & $.10^{b}$ & $3.33^{a}$ & $1.53^{a}$ \\
\hline
\end{tabular}

${ }^{1}$ Includes Carea filifolia.

- Means in the same column within each vegetation class followed by different superscripts are significantly different at the 0.05 level of probability.

Annual grasses were more abundant on gopher-disturbed areas on all sites except silty WP (Table 5). Percentages. of perennial forbs were also greater on disturbed versus undisturbed areas on all sites except silty R. Basal cover of annual forbs was significantly lower on undisturbed range compared to disturbed areas at all research locations (Table 5). Significantly higher percentages of shrubs were found on the disturbed areas on sands NSC and SSC (Table 5). Differences in percentages of shrubs between the two areas were not significant on the silty $R$ and WP sites.

\section{Frequency of Vegetation on Mounds}

Vegetation on less-than-1-year-old mounds was sparse (Tables 6 and 7). Frequency of most perennial grasses increased with increasing mound age. The following increases in perennial grasses from less-than one-year-old to 4-year-old mounds were observed on the sands range site: blue grama

Table 4. Bare soil, litter cover, and vegetation cover $(\%)$ on gopher-disturbed and undisturbed areas.

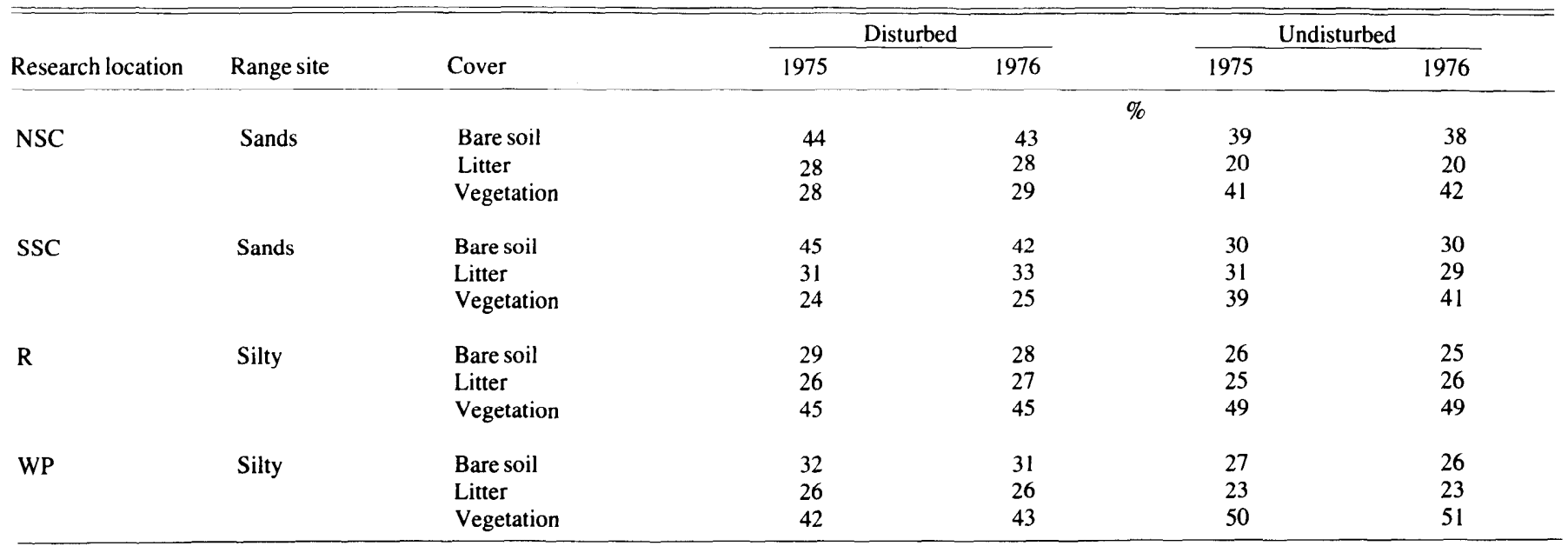


Table 6. Frequency percentage of vegetation as influenced by increasing age, on gopher mounds at the South Sand Canyon research site (sands range site), 1976.

\begin{tabular}{|c|c|c|c|c|c|}
\hline \multirow[t]{2}{*}{ Vegetation class } & \multicolumn{5}{|c|}{ Mound age in years } \\
\hline & $<1$ & 1 & 2 & 3 & 4 \\
\hline \multicolumn{6}{|l|}{ Perennial grasses } \\
\hline Blue grama ${ }^{1}$ & 2 & 9 & 13 & 15 & 18 \\
\hline Indian ricegrass & 0 & 15 & 19 & 8 & 3 \\
\hline Needleandthread & 0 & 38 & 53 & 59 & 63 \\
\hline Prairie junegrass & 0 & 8 & 11 & 14 & 19 \\
\hline Prairie sandreed ${ }^{1}$ & 4 & 19 & 24 & 51 & 56 \\
\hline Red threeawn & 0 & 1 & 2 & 3 & 0 \\
\hline Sand bluestem ${ }^{1}$ & 2 & 14 & 18 & 21 & 24 \\
\hline Sand dropseed & 0 & 30 & 31 & 26 & 20 \\
\hline Sandhill muhly & 0 & 5 & 5 & 6 & 6 \\
\hline Tall dropseed & 0 & 0 & 3 & 3 & 4 \\
\hline Western wheatgrass & 0 & 5 & 14 & 21 & 24 \\
\hline \multicolumn{6}{|l|}{ Annual grasses } \\
\hline Downy brome & 0 & 0 & 1 & 1 & 2 \\
\hline \multicolumn{6}{|l|}{ Perennial forbs } \\
\hline Heath aster & 0 & 0 & 1 & 0 & 0 \\
\hline Lemon scurf pea ${ }^{1}$ & 5 & 8 & 14 & 8 & 6 \\
\hline Plains pricklypear ${ }^{1}$ & 1 & 0 & 0 & 0 & 0 \\
\hline Purple prairie clover & 0 & 0 & 1 & 0 & 0 \\
\hline Slimflower scurf pea & 0 & 0 & 4 & 3 & 3 \\
\hline Texas croton & 0 & 2 & 2 & 2 & 3 \\
\hline \multicolumn{6}{|l|}{ Annual forbs } \\
\hline Annual eriogonum & 0 & 1 & 1 & 0 & 0 \\
\hline Spotted beebalm & 0 & 3 & 2 & 3 & 1 \\
\hline Beggarticks & 0 & 0 & 0 & 1 & 0 \\
\hline Woolly plantain & 0 & 4 & 4 & 3 & 3 \\
\hline \multicolumn{6}{|l|}{ Shrubs } \\
\hline Cudweed sagewort & 0 & 1 & 1 & 2 & 1 \\
\hline Fringed sagewort & 0 & 3 & 5 & 4 & 4 \\
\hline
\end{tabular}

1 Vegetation originating at soil surface beneath the mound.

$(2-18 \%)$, needleandthread $(0-63 \%)$, prairie junegrass $(0-19 \%)$, and western wheatgrass $(0-24 \%)$ (Table 6). However, three perennial grass species did not increase in frequency throughout the study on the sands range site. Indian ricegrass increased to $19 \%$ on 2-year-old mounds, but then decreased to only $3 \%$ on 4 -year-old mounds. Sand dropseed, not present on less-than-1-year-old mounds, increased to $31 \%$ on 2 -year-old mounds and then decreased to $20 \% 4$ years after gopher disturbance. Sandhill muhly remained at $5 \%$ frequency on 2 -year-old mounds and increased only $1 \%$ the remaining 2 years.

Downy brome, the only annual grass found on mounds at the SSC location, increased only one percentage unit in frequency from 2-year-old to 4-year-old mounds (Table 6). Lemon scurf pea, a common perennial forb in western Nebraska, increased in frequency from 5 to $14 \%$ up to 2 years in age and then decreased to $6 \%$.

Annual forbs did not contribute significantly to vegetation on the sands range site (Table 6). Woolly plantain, the most prominent annual forb occurring on the site, only decreased only one percentage unit in frequency from 1-year-old to 4-year-old mounds. Fringed sagewort, the principal shrubs occurring on the sands range site, increased slightly by the termination of the study.

Only two species of perennial grasses occurred on less-than1 -year-old mounds on the silty range site (Table 7). Blue grama continued to increase in frequency on mounds up to 3 years in age, while the frequency of prairie sandreed was of little
Table 7. Frequency percentage of vegetation, as influenced by increasing age, on gopher mounds on the Rough research site (silty range site), 1976.

\begin{tabular}{|c|c|c|c|c|c|}
\hline \multirow[t]{2}{*}{ Vegetation class } & \multicolumn{5}{|c|}{ Mound age in years } \\
\hline & $<1$ & 1 & 2 & 3 & 4 \\
\hline \multicolumn{6}{|l|}{ Perennial grasses } \\
\hline Blue grama ${ }^{1}$ & 1 & 11 & 62 & 90 & 89 \\
\hline Needleandthread & 0 & 10 & 41 & 48 & 53 \\
\hline Prairie junegrass & 0 & 0 & 0 & 3 & 3 \\
\hline Prairie sandreed ${ }^{1}$ & 1 & 0 & 0 & 0 & 0 \\
\hline Threadleaf sedge ${ }^{2}$ & 0 & 4 & 21 & 29 & 31 \\
\hline Western wheatgrass & 0 & 49 & 63 & 68 & 68 \\
\hline \multicolumn{6}{|l|}{ Annual grasses } \\
\hline Downy brome & 0 & 90 & 93 & 78 & 61 \\
\hline Sixweeks fescue & 0 & 0 & 11 & 13 & 9 \\
\hline \multicolumn{6}{|l|}{ Perennial forbs } \\
\hline Curlycup gumweed & 0 & 1 & 0 & 0 & 0 \\
\hline Rush skeletonplant & 0 & 13 & 6 & 7 & 6 \\
\hline Shell-leaf penstemon & 0 & 0 & 2 & 0 & 1 \\
\hline Silvery lupine & 0 & 0 & 0 & 0 & 1 \\
\hline Slimflower scurf pea & 0 & 8 & 4 & 4 & 1 \\
\hline Western ragweed & 0 & 89 & 64 & 53 & 46 \\
\hline \multicolumn{6}{|l|}{ Annual forbs } \\
\hline Buffalo bur & 0 & 0 & 4 & 0 & 0 \\
\hline Lambsquarters & 0 & 20 & 24 & 18 & 13 \\
\hline Woolly plantain & 0 & 12 & 11 & 12 & 6 \\
\hline \multicolumn{6}{|l|}{ Shrubs } \\
\hline Fringed sagewort & 0 & 5 & 17 & 17 & 18 \\
\hline
\end{tabular}

importance. The perennial grasses needleandthread and western wheatgrass appeared on 1-year-old mounds (Table 7). Needleandthread continued increasing in frequency throughout the study, while western wheatgrass increased on mounds up to 3 years in age and remained constant. Threadleaf sedge increased from $4 \%$ on 1-year mounds to $31 \%$ at the end of the study.

Two annual grass species were prominent on mounds on the silty range site (Table 7). Downy brome was the most abundant plant specics, occurring with a frequency of $90 \%$ on 1-year-old mounds. This grass increased to $93 \%$ on 2-year-old mounds, then decreased in frequency to $61 \%$ on 4 -year-old mounds. The frequency of sixweeks fescue was $11 \%$ on 2-year-old mounds, increased to $13 \%$ on 3 -year-old mounds, and then decreased to 9\% on 4-year-old mounds.

Many perennial and annual forbs were present on mounds on the silty range site (Table 7 ). Western ragweed, with a frequency of $89 \%$, was a dominant species on 1-year-old mounds. However, this perennial forb decreased in frequency with mound age to $46 \%$ on 4 -year-old mounds. As mound age increased, the frequency of many annual forbs decreased. The only shrub present on the silty range site was fringed sagewort. This perennial increased in frequency from $5 \%$ on 1-year-old mounds to $17 \%$ one year later.

\section{Discussion and Conclusions}

Plains pocket gophers reduced forage production at all research locations. The greater forage production found on NSC and SSC (sands range sites) compared to $R$ and WP (silty range sites) was due to range condition. Vegetation on the silty range sites consisted primarily of short and mid-grasses. Vegetation on the sand range sites consisted of more tall and mid-grasses. 
Annual grasses, downy brome and sixweeks fescue were less abundant on the sands range sites than on the silty range sites.

Greater amounts of perennial grasses and fewer forbs on the sands range sites resulted in higher range condition and greater forage production than on the silty range sites. Potential forage production is greater on silty range sites $(3,360 \mathrm{~kg} / \mathrm{ha}$ in favorable years) as compared to sands range sites $(2,800 \mathrm{~kg} / \mathrm{ha}$ in favorable years) (Jensen 1977). However, due to present and past grazing management, greater amounts of short grasses, annual grasses, and forbs were present on the silty range sites, which resulted in lower range condition and forage production. The activity of plains pocket gophers resulted in more bare soil on all research sites. In all instances, litter was more abundant on the gopher-disturbed areas when compared to undisturbed range. Larger amounts of annual grasses, annual forbs, and perennial forbs were present on disturbed areas. Possibly, grazing livestock were not selecting these less palatable species, thus allowing more litter to accumulate.

Higher percentages of basal cover of vegetation occurred on silty range sites than on sands range sites. These higher values were present on both disturbed and undisturbed range. Because larger amounts of the sod-forming short grasses were present on the silty range sites, a larger percentage of the soil surface was occupied by plant bases.

Perennial grasses were less frequent on the gopher-disturbed areas at all research locations. The bulk of the plains pocket gopher diet consists of grasses (Myers and Vaughan 1964). Therefore, lower percentages of perennial grasses would be expected on disturbed areas. Differences between percentages of perennial grasses present on disturbed and undisturbed range were greater on the sands range sites. Because a greater percentage of these species were found on the two sands range sites, a larger reduction occurred. Plains pocket gophers fed on plant roots, and probably preferred the largerrooted species on the sands range sites versus the fibrous-rooted species on the silty range sites. Since more annual forbs were also present on the silty range sites, the gophers were possibly utilizing these species and exerting less pressure on the perennial grasses.

Amounts of annual grasses were greater on gopher-disturbed areas when compared to undisturbed range at all research locations. When gophers create mounds on the soil surface, annuals are usually the first invaders in the pattern of plant succession. Laycock (1958) reported high percentages of annuals growing on northern pocket gopher mounds.

Percentages of perennial forbs were greater on gopherdisturbed areas at all research locations except sands range site $R$. Perennial forbs are not abundant in the climax vegetation. Jensen (1977) stated that perennial grass decreasers composed $65 \%$ of the climax plant productivity on sands sites and $50 \%$ on silty sites and that miscellaneous perennial grasses, forbs, and shrubs together accounted for only $35 \%$ of the climax plant productivity on sands range sites and $50 \%$ on silty range sites. However, as gophers began infesting the area and affecting the range vegetation, forbs were able to successfully compete with the existing vegetation and increased in abundance.

Gopher-disturbed areas also had greater percentages of annual forbs when compared with undisturbed range. Larger numbers of annual forbs occurred on both areas on the silty range sites as compared to the sands range sites. The silty range sites were in lower range condition, and larger amounts of annual forbs were present. Annual forbs readily invaded gopher-disturbed areas as the perennial grasses were reduced in vigor or consumed and as amount of bare soil increased.

Rangeland improvement through natural plant succession was delayed on areas disturbed by plains pocket gophers. Vegetation was sparse on less-than-1-year-old mounds. Frequency of most perennial grasses increased with mound age, while annual grasses and forbs tended to decrease.

Results obtained from this research on the Pepper Creek Ranch do not agree with some previous investigations. Downhower and Hall (1966) stated that plains pocket gophers deserve to be let alone as normal members of the grassland community, and that control measures removed some gophers from grasslands where they did no harm and some good. These results show that plains pocket gophers adversely affect rangeland. Range managers must be aware of the fact that this rodent may interfere with their goal of maximizing rangeland productivity.

\section{Literature Cited}

Beck, Reldon F., and Richard M. Hansen. 1966. Estimating plains pocket gopher abundance on adjacent soil types by a revised technique. J. Range Manage. 19:224-225.

Case, Ronald M., J. Stubbendieck, and Philip S. Gipson. 1976. Plains pocket gophers and their control. Inst. Agr. Nat. Resources. Univ Nebraska. G76-319. 3p

Downhower, Jerry F., and E. Raymond Hall. 1966. The pocket gopher in Kansas. Mus. Natur. Hist. Misc. Pub. 44:1-32.

Ellison, L. 1946. The pocket gopher in relation to soil erosion on mountain range. Ecology 27:101-114.

Fitch, Henry S., and J.R. Bently. 1949. Use of California annual-plant forage by range rodents. Ecology 30:306-321.

Jensell, Peter N. 1977. Range, p. 71-79. In: Larry G. Ragon, Larry D. Worth, Max A. Sherwood, and Michael L. Fausch, Soil survey, Dawes County, Nebraska. U.S. Dep. Agr. Soil Conserv. Service.

Laycock, William A. 1953. An ecological study of the pocket gopher (Thomomys talpoides tenellus Goldman) in the Jackson Hole region of Wyoming. MS Thesis, Univ. Wyoming, Laramie. 65p.

Laycock, William A. 1958. The initial pattern of revegetation of pocket gopher mounds. Ecology. 39:346-351.

Moore, A.W., and E.H. Reid. 1951. The Dalles pocket gopher and its influence on forage production of Oregon mountain meadows. U.S. Dep. Agr. Circ. 884. 36 p.

Myers, Gary T., and Terry A. Vaughan. 1964. Food habits of the plains pocket gopher in eastern Colorado. J. Mammal. 45:588-598.

Turner, George T. 1969. Responses of mountain grassland vegetation to gopher control, reduced grazing, and herbicide. J. Range Manage. 22:377-383

Turner, G.T., R.M. Hansen, V.H. Reid, H.P. Tietjen, and A.L. Ward 1973. Pocket gophers and Colorado mountain rangeland. Colorado State Univ. Agr. Exp. Sta. Bull. 554S. 90 p.

U.S. Department of Commerce. 1973. Monthly normals of temperature, precipitation, and heating and cooling degree days, 1941-1970. Climatology of the U.S., No. 81. Washington, D.C. 13p. 